\title{
Farmer experience of pluralistic agricultural extension, Malawi
}

Article

Accepted Version

Chowa, C., Garforth, C. and Cardey, S. (2013) Farmer experience of pluralistic agricultural extension, Malawi. Journal of Agricultural Education and Extension, 19 (2). pp. 147-166. ISSN 1750-8622 doi:

https://doi.org/10.1080/1389224X.2012.735620 Available at https://centaur.reading.ac.uk/29378/

It is advisable to refer to the publisher's version if you intend to cite from the work. See Guidance on citing.

To link to this article DOI: http://dx.doi.org/10.1080/1389224X.2012.735620

Publisher: Taylor and Francis

All outputs in CentAUR are protected by Intellectual Property Rights law, including copyright law. Copyright and IPR is retained by the creators or other copyright holders. Terms and conditions for use of this material are defined in the End User Agreement.

\section{www.reading.ac.uk/centaur}

\section{CentAUR}

Central Archive at the University of Reading 
Reading's research outputs online 


\section{Farmer experience of pluralistic agricultural extension, Malawi}

\section{Clodina Chowa ${ }^{*+}$, Chris Garforth ${ }^{+}$and Sarah Cardey $^{+}$}

* Agricultural Extension Service, Ministry of Agriculture, Irrigation and Water Development, Government of Malawi

${ }^{+}$School of Agriculture, Policy and Development, University of Reading, UK

Corresponding author:

Professor Chris Garforth, School of Agriculture, Policy and Development, University of Reading, PO Box 237 Reading RG6 6AR, UK. Telephone: +44 (0)118 378 8134. Fax: +44 (0)118926 1244. Email: c.j.garforth@ reading.ac.uk

\section{Acknowledgements}

The fieldwork for this research was funded by a $\mathrm{PhD}$ scholarship from Flanders International Cooperation Agency (FICA) through the 'Support for Agricultural Extension Training and Services Programme, Malawi' held by the first author. The authors are grateful for the time and insights given by farmers and other participants in the research, and to two anonymous reviewers for their constructive comments on an earlier version of the paper. 


\title{
Farmer experience of pluralistic agricultural extension, Malawi
}

\begin{abstract}
Purpose

Malawi's current extension policy supports pluralism and advocates responsiveness to farmer demand. We investigate whether smallholder farmers' experience supports the assumption that access to multiple service providers leads to extension and advisory services that respond to the needs of farmers.
\end{abstract}

\section{Design/methodology/approach}

Within a case study approach, two villages were purposively selected for in-depth qualitative analysis of available services and farmers' experiences. Focus group discussions were held separately with male and female farmers in each village, followed by semi-structured interviews with 12 key informants selected through snowball sampling. Transcripts were analysed by themes and summaries of themes were made from cross case analysis.

\section{Findings}

Farmers appreciate having access to a variety of sources of technical advice and enterprise specific technology. However, most service providers continue to dominate and dictate what they will offer. Market access remains a challenge, as providers still emphasize pushing a particular technology to increase farm productivity rather than addressing farmers' expressed needs. Although farmers work in groups, providers do not seek to strengthen these to enable active interaction and to link them to input and produce markets. This limits farmers' capacity to continue with innovations after service providers pull out. Poor coordination between providers limits exploitation of potential synergies amongst actors.

\section{Practical implications}

Services providers can adapt their approach to engage farmers in discussion of their needs and work collaboratively to address them. At a system level, institutions that have a coordination function can play a more dynamic role in brokering interaction between providers and farmers to ensure coverage and responsiveness.

\section{Originality/value}

The study provides a new farmer perspective on the implementation of extension reforms.

\section{Keywords}

technology, innovation, demand-driven, pluralistic extension, input and output markets, extension reform

\section{Paper type}


Original research paper

\section{Introduction}

An estimated $75 \%$ of resource poor people in developing countries rely on agro-based economic activities for their livelihoods (World Bank, 2008). In Malawi, economic growth depends on agriculture: out of a population of 13 million, $80 \%$ of the productive labour force are employed in the agriculture sector (GoM, 2009; GoM, 2010a). Agriculture in Malawi is divided into estate and smallholder sectors. Land under estates is held on leasehold or freehold tenure systems while in the smallholder sector land is held under the customary law (Scarborough, 1990; Cromwell and Winpenny, 1993; Harrigan, 2003). Masanjala (2006) added that apart from the difference in land tenure system, farming practices differ in that estates practise capital intensive farming focusing on production of high value crops such as tea, coffee, sugar and tobacco for the export market while the smallholder sector is characterized by resource constraints. Nevertheless, the smallholder sector is the main producer of food commodities such as maize, rice, horticultural crops and livestock products and also complements the commercial sector in the production of high value crops for export. It is estimated that $70 \%$ of Malawi's agricultural GDP comes from the smallholder sector (GoM, 2010a).

Estates source extension and advisory services from private extension agents while smallholders rely on public sector, civil society and non-governmental organisations (NGOs). Growth of agriculture in Malawi faces similar challenges to those experienced in many parts of the world, especially in developing countries. These include a growing population that creates a scramble for land for settlement and farming, HIV and AIDS pandemic, changing economic environment and the effects of climate change (World Bank, 2008). Agricultural research and extension, which are crucial to meeting these challenges, have been critiqued for using approaches that are not responsive to the needs of their clientele. The last decade has seen a general shift in thinking about extension from a linear, technology transfer, 'adoption of innovations' approach to recognition of the multiple roles of a wide range of actors within 'innovation systems' (Garforth, 2011). This shift in thinking has influenced, and been influenced by, shifts in policy towards supporting pluralistic provision of services which are more responsive to farmer demand (ibid.). There is interest among policy makers, service providers and academics in finding out whether these changes have made any difference to farmers' access to services that support their efforts to secure livelihoods for themselves and their families. This paper explores this question from the perspective of smallholder farmers in Mchinji district in Malawi.

This paper is organised into seven sections. Following this introduction, concepts of demanddriven and pluralistic extension are explored, providing a theoretical framing for the empirical study. Then, the context of extension and extension reforms in Malawi is outlined and the research questions presented. The following section discusses research methodology 
and methods, while the next presents research findings. The findings are discussed and conclusions presented in the final two sections.

\section{Theoretical framework}

The argument for reforms to make extension more demand-driven is based on two main strands of thinking. First, top-down, supply-driven extension, embodied par excellence in the discredited Training and Visit system (Anderson and Feder, 2004), has been shown to be effective only in very specific contexts, far from the diversity and pluri-activity (Brookfield, 2008) that characterise smallholder farms in most of sub-Saharan Africa. Second, there are significant market failures in the demand and supply for agricultural advice and information, partly because of the public good nature of information itself but also because of high transaction costs, information asymmetry and the likelihood that farmers discount the potential value of information and advice from service providers (Benyon et al., 1996). Consequently, both demand and supply have to be supported by public funding, and a degree of regulation is needed to assure quality, to ensure farmers have access to adequate information and advisory services that enable them to achieve the potential of their farm enterprises (Chipeta, 2006). Demand-driven extension requires pluralism in service provision on the supply side. Farmers can only exercise choice if there is a range of service providers to choose from. Encouraging pluralism is a recurrent feature of extension reform since 2000 (Rivera and Alex, 2004; Chipeta et al. 2008), for example in Uganda, Kenya and Malawi. In the case of Malawi, the main thrust of extension reform has been to promote pluralism and create institutions at local level to enable farmer demand to be articulated and then met with a coordinated response.

However, institutionalising farmer demand in extension reform has proved problematic. Vouchers, for example, which farmers or farmer groups can 'spend' on advisory services from providers of their choice, may simply give farmers a choice between two or more supply-driven offers rather than access to services which respond to specific needs identified by or from clients (Bebbington and Sotomayer, 1998; Klerkx et al., 2006). They are also open to misuse, with vouchers becoming tradable commodities between farmers who would rather turn them into cash with the collusion of service providers. Similarly, Parkinson's assessment of farmer empowerment and the expression of 'farmer demand' within Uganda's National Agricultural Advisory Services through farmer interest groups is that these elements of extension reform are of much less importance to farmers than to donors and academics, to the extent that farmers are reluctant to commit time to the institutional processes of identifying and responding to their advisory service needs (Parkinson, 2009).

The research question addressed by this paper is whether extension reforms in Malawi are in practice leading to farmers' experiencing more demand-driven advisory services. Research on the local experience of pluralistic, demand-driven extension lends itself to a farmer-centric innovation systems perspective. Innovation systems can be seen as large-scale constructs, such as sectoral or national systems of innovation; Juma (2011), for example, uses such a construct to explore what needs to be done to improve the institutional and physical 
infrastructure that can support innovation and agricultural development in African countries. But such constructs present what those outside the smallholder farmer's context think should or does happen, rather than the reality experienced by farmers. In the context of change and innovation at farm level, therefore, a construct that identifies the various sources of information and influence that contribute to a farmer's decision to make changes to his or her farm enterprise or farming practice is more helpful (Assefa et al., 2009). Such a construct can only be built empirically in a specific context, but a typical set of innovation system actors can be described as in Figure 1, with farmers or farm households as the principal actors while the others range from individuals with whom farmers interact (such as local traders) to institutions (including regulations and land tenure systems) which help to determine farmers' options and incentives. This should not be interpreted as a 'designed' system, but as a construct for describing and analysing the reality that farmers experience: in any specific context, some of these actors may be absent, and some will be more accessible and influential than others.

\section{[Figure 1 about here]}

Ever since Stephen Biggs proposed a 'multiple sources of innovation model' for understanding technological change in smallholder agriculture (Biggs, 1990), interest in innovation systems as a way of exploring farmers' response to challenge and opportunity has grown. Innovation system concepts have been reflected in recent extension policy reforms (for example, in India (Sulaiman and Hall, 2002) and Kenya (Government of Kenya, 2007)) while Spielman et al. (2011) have shown how they can be used to explore innovation and change within smallholder farming systems. Above all, an innovation systems perspective puts the contribution of information and advice from service providers into context, recognising that there are many other factors that influence farmers' ability and willingness to make changes, and the extent of any consequent improvements in productivity, income or livelihoods. This study considers how pluralistic extension provision fits within the innovation system that farmers experience, and whether providers could be doing more to remove bottlenecks to innovation processes.

\section{Agricultural extension and advisory services in Malawi}

Agricultural extension in Malawi has evolved since the colonial era, which ended in 1964. Since then extension has been provided under different labels such as M'Chikumbi, Modified Training and Visit and Participatory Approach (Masangano and Mthinda, 2010). According to Kabuye and Mhango (2005) and Knorr and Gerster-Bentaya (2007), under the preindependence Master Farmer Approach selected farmers received preferential treatment from the colonial government in terms of training and inputs to mount demonstrations. This was in anticipation that the indigenous farmers would follow what was being demonstrated. The approach created resentment from the would be followers as the demonstrators were thought to be traitors by fellow Malawians (Kabuye and Mhango, 2005; Knorr and Gerster-Bentaya, 2007; Masangano and Mthinda, 2010). After independence, the programme was modified to the M'Chikumbi (Farmer) Programme. The first State President late Ngwazi Hastings 
Kamuzu Banda called himself M'Chikumbi (Farmer) number 1 (GoM, 2000; Kabuye and Mhango, 2005) to demonstrate high level political support to the development of agriculture in the country. It targeted commercial farmers on the premise of boosting economic growth through private sector growth. All farmers deemed successful were given the prestigious title of M'Chikumbi number 2. Although the approach registered remarkable success, unlike the Master Farmer approach, it was highly politicised as it concentrated on those who had a political inclination towards the ruling party (Knorr and Gerster-Bentaya, 2007). It also discriminated against smallholder farmers.

In order to increase farmer coverage and reach out to marginalised groups, the Modified Training and Visit (T\&V) system was introduced in 1982. The approach was also widely used in many Asian and African countries to improve agriculture (Douthwaite, Keatinge et al., 2001; Anderson and Feder, 2003; Anderson and Feder, 2004; van den Ban, 2006). The area covered by each frontline extension worker was demarcated into eight subsections known as blocks which were visited at least once a fortnight (Kabuye and Mhango, 2005; Masangano and Mthinda, 2010). A monthly visitation route map enabled supervisors to track extension workers' movements. Reality revealed that $\mathrm{T} \& \mathrm{~V}$ resulted in increased operational costs, denied extension officers creativity as they were expected to follow a fixed visitation schedule, left disadvantaged people such as women farmers unreached by extension and was considered not responsive to farmers' needs (Farrington 1995; Axinn 1997; Garforth 2005).

Disenchantment with T\&V coincided with widespread moves towards more open democracy in sub-Saharan Africa in the 1990s. Provision of services began to reflect the new dispensation, as the need for involvement and participation in decision making platforms of people at grassroots level became increasingly recognised. Participatory approaches were therefore promoted in advisory services to address shortcomings of previous approaches. In Malawi, the decentralisation process of the public sector adopted in 1998 (GoM, 1998) and of agricultural extension services in 2000 (GoM, 2000) provided opportunities for improving provision of advisory services by allowing pluralism in service provision. Governance structures such as the Village Development Committee, Village Agriculture Committee and Area and District Stakeholder Panels were established to provide platforms for interaction among stakeholders in the process of demand articulation and responding, with a District Agricultural Executive Coordinating Committee responsible for overall coordination.

However, implementation of pluralistic agricultural extension has met mixed views among actors in Malawi. Studies (Knorr and Gerster-Bentaya, 2007; Chinsinga, 2008; Masangano and Mthinda, 2010) acknowledge that diversity in sources and type of services provided is a result of availability of multiple players in agricultural advisory services. However, pluralism has also created competition amongst actors which has been manifested in coordination challenges. For example, Chinsinga's (2008) attempt to delineate functions of the public and private sectors in Thyolo and Dedza districts under a decentralized extension system reveals overlaps arising from inadequate policy articulation and enforcement by the public sector. However, these studies focussed on district and regional agriculture offices and did not articulate experiences of farmers from the village level perspective. The present study was 
therefore undertaken to understand experiences of male and female farmers in selected villages with pluralistic extension. The key question addressed in this research is what changes has pluralistic demand driven extension made from the farmers' perspective?

\section{Methodology}

The research was based on a constructivist epistemology, which recognizes multiple realities based on the perspectives of different social actors. To allow farmers' perspectives to emerge, the research took a qualitative case study approach; two villages in Mchinji District of Malawi, Gomani II and Matimba, were purposively selected as cases. The first author, with support of the district agriculture office, identified villages where at least five innovation system actors had come from outside the village to work with farmers on different agricultural and non- agricultural initiatives. Qualitative methods included four focus group discussions (FGDs) with separate groups of male and female farmers $(n=32)$. Each FGD comprised eight members to allow maximum interaction; each group met three times, allowing in-depth follow up of emerging themes and internal validation of findings. Open ended questions and probing enabled the collection of a rich set of data. Key informant interviews (KII) $(n=12)$ and non-participant observation enabled triangulation and a further check on validity. Discussion for both the FGDs and the KIIs focussed on agricultural enterprises in the village, actors and diversity of activities undertaken, process of external actors when entering the village, and historical trends of innovation in the village regarding what farmers consider to be key enterprises. Discussions also covered how farmers and other actors engage with each other on interventions in the village, types of information and knowledge systems used and their perceptions on pluralistic extension. For this part of the discussion, questioning was guided by selected 'windows' from the Rapid Appraisal of Agricultural Knowledge Systems (RAAKS) toolkit (Engel and Salomon, 1997). Participants in the FGDs were recruited on the basis that they were full time farmers, residents of the selected villages and undertaking a variety of agricultural enterprises for food and income security. Key informants were recruited through snowballing sampling. The following criteria were used to identify the first respondent in each village: regular attendance at agricultural meetings, quality of contributions to discussion during meetings and role modelling in agriculture activities. Analysis of the data was based on the identification of recurring themes. Computer programme Microsoft Excel was used to create spreadsheets for cross case analysis.

The researchers sought to achieve a valid representation of farmers' views within the case study villages through triangulation (FGDs, interviews and observation) and through repeated rather than single meetings with focus groups. It is possible that there was some bias in selection of key informants, as interviewees are more likely to suggest people similar to themselves in the snowballing procedure. In keeping with accepted tenets of qualitative research, enquiry in the villages continued until no new conceptual insights were emerging (Strauss and Corbin, 1998). While the findings cannot be regarded as representative beyond the case study villages as these were purposively rather than randomly selected, they can be 
used to suggest themes and hypotheses for future research in Malawi and elsewhere where decentralised, demand-drive extension reforms are in place.

\section{Results}

Findings related to the experiences of farmers with pluralistic extension in the study are presented under the following sections: factors influencing choice of key enterprise, information and innovation systems in the village, farmers' perceptions on other innovation system actors, farmers' perceptions on pluralistic extension system, and access to input and produce markets. The sections were derived from the theoretical framework; the themes within each section emerged from the analysis of the qualitative data.

\section{Factors influencing choice of key enterprise}

Male and female farmers in Matimba and Gomani II villages grow a variety of crops such as maize, rice, soyabeans, beans, potatoes, tobacco, groundnuts, pigeon peas, fruits and vegetables. They also raise livestock such as chickens, rabbits, goats and cattle. Slight differences were noted in the list of enterprises mentioned by male and female farmers groups within the village and across villages. Men mentioned more crops and livestock than women whose lists focused on food crops. However, when farmers were asked to identify the three priority enterprises, responses in both villages were similar in that maize, groundnuts and soyabeans were chosen. It was agreed with the farmers that priority enterprises are those that a household grows every year, while a key enterprise is the one that enables the household to have food and other basic household needs. It was observed that farmers in the two villages identified different key enterprises, while there was no difference between choice of key enterprise for male and female farmers in the same village: male and female farmers in Matimba village chose groundnuts while in Gomani II maize was chosen.

Reasons for choosing the key enterprise, however, were different between men and women farmers. The women in Matimba village justified their choice of groundnuts as a key enterprise due to its potential to give higher yields, profitability in terms of high income returns, market availability and opportunities for agro-processing. Others mentioned food security and non requirement for chemical fertilizer. Men from Matimba village mentioned factors such as amount of capital investment required in terms of seeds and fertilizers, high income returns and viability of the enterprise to substitute tobacco as cash generator. Men in Gomani II village considered the high income returns the enterprise can give, profitability and household food security requirements. They also noted that the ease with which the farm produce can be exchanged for some basic household commodities such as salt, soap and clothes in case of non-availability of cash markets is also an important factor when making decision on choice of key enterprise. Responses for women in Gomani II village focussed on the ability of the enterprise to provide food security and income for their households.

Information and innovation systems in the villages 
Pluralism has resulted in farmers in the study sites having access to more, and more diverse, sources of extension and advisory information. Information and knowledge are prerequisites for innovation: farmers need information and knowledge in order to adapt, adopt a technology, change ways of doing things, access inputs, produce agricultural outputs, add value and market their produce. They obtain information and knowledge from a variety of sources within and outside the village covering areas such as microfinance, extension and training and social welfare. In the study, some minor differences were noted in the list of sources of information mentioned by male and female farmers, and men overall mentioned more sources than women (Table 1). For example, both women and men in Matimba village mentioned Microloan and FITSE (Finance Trust for the Self Employed) as actors providing microfinance services, but men mentioned a third (MRFC - Malawi Rural Finance Company) as well. Similarly, both men and women in Matimba mentioned that NASFAM (National Smallholder Farmers' Association of Malawi) provides extension and advisory services on groundnuts in conjunction with an extension worker from the Ministry of Agriculture, but four of the other organisations offering extension services to the village were mentioned only by the men. Similar observations were made in Gomani II village. Non-farmer actors in the two villages can broadly be categorised into three based on the services they provide: microfinance, extension and training, and social services. Farmers in both villages explained how activities of non-agriculture related actors indirectly supported agricultural development in the village. Farmers explained how activities of non-agriculture related actors indirectly supported agricultural development in the village. For example farmers in both villages mentioned that the District Assembly's social cash transfer scheme (Table 1) has helped families with orphans not only to pay school fees for the children but also to procure seed and fertilizers to produce food for the household. Table 1 provides the categories and names of key actors identified in both villages.

\section{[Table 1 about here]}

Farmers noted two types of actor providing microfinance services; those that provide loans from outside the village and local organisations within the village. Microloan, MRFC and FITSE provide loans with resources from outside the village. Their loans are categorised as business and agricultural loans and have repayment periods that commence after two weeks and seven months respectively. On the other hand local organisations mobilise cash that is loaned to members and non members. For example, CADECOM (Catholic Development Commission) encourages women to mobilise cash from within the village. The women give out the money as loans to each other under Village Savings and Loans scheme. It was further indicated that the organisation targets women farmers as an economic empowerment strategy. However, some male farmers mentioned that they benefit from the group by accessing the loans directly or through their spouses. Further discussions about the scheme revealed preference for loans from village savings by both male and female farmers due to relatively low interest charged on the capital compared to what they pay for loans from other sources. However one of the challenges encountered is to meet the demand for loans due to the limited cash volume raised. 
For extension and training services it was noted that private and public extension organisations provide information and knowledge that cover a wide range of activities such as production of crops, raising of livestock, raising of tree nurseries, health and sanitation, reproductive health, agro-processing, group organisation, climate change adaptation, gender and literacy classes. Actors use different methods such as demonstrations, village meetings, farmer study tours, radio programmes, classroom training sessions and field days to communicate information and knowledge. In Gomani II village, Farmers' Voice Radio and Mudzi Wathu Community Radio Station were singled out as actors that encourage farmers to use the radio to access agricultural messages. Farmers in the village formed a radio listening club which meets every week to listen to agricultural radio programmes. A dairy project benefiting twenty households in the village was mentioned as an outcome from radio listening: farmers reported that they mobilised themselves after listening to a radio programme and approached the responsible organisation which was not operating in the village at that time. Farmers also expressed satisfaction with the services from the community radio station because the presenters use their language 'Chisenga' which they understand easily. They also stated that the radio station gives them opportunity to announce their own messages at a minimal fee. However frequent breakdown of the transmitters frustrates the initiative. Further probing revealed that farmers in both villages also access agricultural extension messages aired on public and private radio stations with nationwide coverage.

Social organisations providing care and support to vulnerable groups in the villages were also considered important. Respondents noted that due to HIV and AIDS pandemic the villages have increased numbers of vulnerable persons such as orphans and those infected. They explained that the effects of the pandemic exert demands on their resources such as time and finances which they could otherwise invest in agriculture. Both male and female farmers indicated that programmes such as the Social Cash Transfer Scheme (a UNICEF / Government of Malawi initiative) provide relief in form of cash income to vulnerable persons to cater for basic needs such as food and school fees. It was also indicated that in the absence of external support, village members have a social responsibility to contribute in cash or kind to support the vulnerable in the village.

\section{Farmers' perceptions of external actors}

To explore their perception regarding services they receive from various actors, farmers were asked to rate the actors as key or not and give reasons for their responses, using RAAKS Window A2 (Engel and Salomon, 1997). Most of the actors were rated as key by both male and female farmers. Farmers cited different reasons for key ratings given to some actors, which include ability to respond to farmers' problems, their role in ensuring farmers have access to inputs and produce markets and promoting farming business through formation of farmer cooperatives. Conservation of natural resources was also considered a key factor as it ensures availability of trees for home use such as fuel wood and poles for construction. Some actors such as Ministry of Agriculture, Health Extension Workers, NASFAM, Farmers Voice Radio and Mudzi Wathu Community Radio Station were identified as very reliable sources of 
information. Participants indicated that the public sector extension workers from Ministries of Agriculture and Health are always within farmers' reach and follow up on farmers' activities. NASFAM was also rated highly because, according to the farmers who are members of groundnut growing groups, it supports them through the value chain of groundnut enterprise from seed acquisition, to production, grading and marketing. In order to encourage farmers to join their local Clubs and Action Groups, NASFAM provides competitive prices for groundnuts as long as farmers grow the required varieties and grade the produce before selling. On the other hand, some farmers indicated that despite competitive prices, conditions such as payment of membership fees, delayed opening of marketing season and grading deter them from joining NASFAM groups.

Actors not rated as key were seen by farmers as inflexible, with some imposing unrealistic demands without considering farmers' social and economic situations and which may conflict with advice from other actors. The availability and use of crop residues is an interesting example. Male farmers in Gomani II village said that a project promoting commercial smallholder agriculture through conservation farming required them to lay crop residues on a two acre piece of land, which they saw as unrealistic because it was laborious. They also reported that another actor promoting dairy farming in the same village advised them to preserve their crop residues for feed and bedding. Farmers felt frustrated and failed to make a decision as both conservation farming and dairying enterprises seem potentially lucrative. The challenge was that one actor used amount of crop residues collected and preserved, while the other one used size of land covered with crop residues as criteria to participate in their programmes. They also felt that the introduction of both programmes was ill-timed, as most of the crop residues had been destroyed by animals that roam in the fields after harvest, burnt in situ or used for fuel.

Another reason cited for not rating actors as key were that they promote enterprises that require expensive inputs, yet they do not facilitate farmers' access to input and produce markets. Actors in the microfinance sector were faulted for short repayment period on loans and high interest rates. A repayment period of two weeks for non-agricultural loans was considered an unrealistic period of time in which to do meaningful business. In addition, both male and female farmers cited the practice by actors of each forming separate operating committees as a weakness: they said that this tendency consumes their time through attending meetings as some of them belong to more than one committee.

\section{Farmers' experience with pluralistic extension}

Farmers in the two villages expressed mixed feelings regarding their experiences with pluralistic extension. On the positive side, farmers mentioned that pluralistic extension has provided opportunity to access diverse information and knowledge from different actors. This was evident from the fact that more than ten external actors were operating in each of the villages (Table 1). It was mentioned that some farmers have increased productivity in key enterprises through increased access to improved agricultural technologies, such as improved seeds, timing and placement of fertilizers, ridge and planting hole spacing. Table 2 presents 
some of the innovation that has occurred in the villages, including new technologies farmers have learnt and applied in their key enterprises of maize and groundnuts, since the move towards pluralistic extension provision began. (Although the new extension policy was not brought in until 2000, the public sector monopoly began to give way to multiple service providers at the same time as the move towards multi-party democracy. FGD participants and interviewees found it easier to relate to a historical political event - multi-party elections in 1994 - than to the introduction of a new policy.)

\section{[Table 2 about here]}

The other experience mentioned by respondents is that pluralism has enhanced social learning amongst farmers and with other actors. Learning takes place during events such as on-farm demonstration, training sessions at training centres, field days and farmer tours. Farmers also indicated that they are encouraged by extension workers to seek information from fellow farmers. To that effect Lead Farmers are identified by village members and trained by external actors in specific technologies in order to improve their competence. The initiative was introduced in the public sector through animal health programmes in 1999 by the Danish International Development Agency (DANIDA) (GoM, 2010b). Farmers were trained to provide livestock services such as artificial insemination, vaccination and dipping (ibid). In extension and advisory services the initiative is implemented under different labels such as key men, farmer facilitator or farmer volunteers by actors in the public and private sector. Implementation frameworks also differ. During the research, farmers indicated that they seek information from those who they perceive to have mastered a particular technology and where there is adequate evidence that it has worked on their farm.

Farmers reported a positive experience in the responsiveness of some actors. However, out of the many actors operating in the villages, only two were repeatedly mentioned by the farmers in the two villages as being responsive to their needs. One actor responded to farmers' request for mosquito nets to prevent malaria attacks on children although their main activities in the area focused on food security. In addition farmers reported that this actor also facilitated acquisition of a groundnut oil processing machine for a Farmers' Cooperative group as an income generating activity in one of the villages. Women in Matimba village mentioned that the processing machine has eased their access to cooking oil as they can get their nuts pressed at the mill. In the discussion it was clear how female farmers linked availability and access to the processing machine to improvement of nutrition status of their family members. On the other hand male farmers appreciated the convenience of shelling groundnuts for marketing. The other actor responded to farmers' request for dairy farming in Gomani II Village. Twenty households have benefitted from the initiative which operates as a 'pass on' programme: they have each received a cow as a loan which they repay by 'passing on' a female calf that can be given to another household.

However, farmers also indicated some negative experiences with pluralistic extension. They identified issues including the creation of parallel operating structures such as committees, 
poor interaction with farmers, inadequate linkage to input and produce markets and poor exit strategy as some key weaknesses. It was learnt that each of the external actors creates a committee at village level to oversee its activities there. Farmers viewed this as a weakness because it creates duplication and conflict in the roles and functions of the committees some of which have similar activities. Farmers perceived as active by fellow village members belong to at least three committees related to agriculture; there was also an increased chance of active farmers belonging to committees formed by actors in sectors outside agriculture. Despite the creation of committees, farmers generally rated their interaction with external actors as not satisfactory. They felt that actors enter the village to inform them of activities they plan to implement and not to discuss with them the plans so as to incorporate farmers' views, opinions and needs. Some farmers mentioned that they endorse projects that they may not fully comprehend at meetings which actors conduct to sensitize them on new initiatives. Farmers in Gomani II village revealed that as a result of a meeting by a Peace and Justice NGO, they have realised their roles to ensure that services provided by actors respond to their demands and needs. Farmers mentioned that despite this knowledge, they still need confidence and coaching to actively engage the actors.

Availability and access to input and output markets was also mentioned as a challenge by farmers. Farmers stated that they travel long distances to markets due to the absence of agro dealers within the villages. This affects adoption of some technologies, as some farmers cannot travel the long distances to procure farm inputs. This may result in such farmers continuing to use inferior varieties of seeds. Farmers in Matimba indicated that they travel over 10 to 15 kilometres on average to the nearest agro dealers to buy improved fertilizers, seeds and herbicides. They also buy tools like hoes and slashers. It was learnt that they rely on extension workers operating in their villages for advice on how to use the inputs, as the agro dealers only display advertisements of their products and not information on usage. Increased costs of farm inputs and inadequate capital to invest in agricultural enterprises were also cited as hindrance to adoption of some technologies such as use of herbicides and improved seeds and fertilizers. Farmers stated that there are not enough microfinance institutions that can offer soft loans to invest in farming business. It was also learnt that markets for farm produce are not accessible resulting in farmers not reaping economic benefits from their harvest. Farmers sell farm produce to 'vendors' who they indicate use uncertified weighing scales and offer low prices to farmers for their produce. They described vendors as people who do untrustworthy business. Views on use of manipulated scales are shared by Chinsinga (2008) who describes vendors as smallscale private traders who offer market alternatives to farmers in remote areas. They move around during harvest periods buying farm produce which farmers would otherwise be stranded with in the absence of organised access to markets.

Unclear exit strategy by the actors was mentioned as another weakness. Most actors withdraw abruptly from the villages without adequate notice to the farmers and the village leadership. Abrupt exit by actors affects continuity of activities in the village as farmers are not prepared to take over responsibility and own the project activities. Some farmers suggested that there 
is need to let them know the duration the actors will operate in the village at the beginning of the project interventions and coach them on how they can carry on with the activities. On the other hand farmers appreciated the move by one NGO to let them know about the phasing out of a project at least three months in advance, although they felt that the period was not adequate to prepare them for taking over responsibility.

\section{Discussion}

It is not the purpose of this paper to describe and analyse local innovation systems in detail. However it is quite clear from the findings that the farmers acknowledge a wide range of innovation system actors, including their fellow farmers. They identify different kinds of support and services - financial services, farming inputs, market access, processing technology, training, knowledge, information - that enable them to make positive changes on their farms and in their agricultural enterprises. They also report how weaknesses or gaps in service provision constrain their ability to develop their farms. The opening up of the extension service landscape to multiple providers has enriched the innovation system in terms of the number and range of services available, but has left farmers with serious difficulties, particularly with respect to market access. Extension provision is now undeniably pluralistic; however it does not seem to have become more demand-driven.

For the study participants, farming meets more than a single objective and the relative importance of objectives may differ between men and women in farming households. Each gender has what can be considered important factors in making decisions of which key enterprise to focus on. Male farmers indicated that low capital investment requirement, market availability and high returns from the enterprise are key factors in decision making, in addition to food security requirements. Women highlighted food security, nutrition for the family and market availability as the main factors considered for choosing a key enterprise. It can therefore be suggested that men consider business related factors in decision making more than women because they consider capital investment and financial returns in making decisions. This view is supported by studies conducted by Carr (2008) in Ghana's Central region which indicated that although men and women grow similar crops, men sell more of what they grow than they use for home consumption. In addition Chipeta (2006) suggested that food security initiatives are better channelled to women farmers, as they are more concerned with achievement of household food security that men. On the other hand, it could be argued that economic needs of women farmers should be seriously considered, as they may sell the food to generate cash income in order to address other household needs. The approach of focusing business opportunities only on men may further lock women into a poverty cycle. However, in the present study, business advice and marketing services were among the key weaknesses of the innovation system reported by both men and women farmers; while the different needs and priorities of men and women do not seem to have been addressed by those providing services in the study villages.

The findings indicate that farmers have learnt more about technological innovations to increase productivity than how to organise themselves to engage with external actors and 
access markets. Both male and female farmers demonstrated understanding of production technologies such as cultural practices, improved varieties and breeds and the relevant information to enable them to increase productivity. Increased access to diverse information and knowledge was attributed to availability of different actors in the villages. Rating their perceptions of information and knowledge accessed from the actors suggest that they need information beyond agricultural technology, such as how to access markets, reproductive health, climate change mitigation and adaptation, care and support for orphans and other vulnerable people in the village, and village savings and loans. The need for such information was justified on the basis that non-agriculture related issues directly or indirectly affect farm productivity by exerting pressure on resource requirement such as time, food and cash income.

Poor linkage to input and produce markets despite the availability of many actors was singled out as the main challenge by many farmers. Actors encourage them to produce, but do not support them to access reliable markets. Although both input and output markets are a challenge, the absence of reliable and organised produce markets takes away the hope from farmers to gain economic empowerment from what they raise and grow. Farmers rely on vendors who they describe as exploiters because they use non-certified weighing scales and dictate farm produce prices which farmers perceive to be low. Problems in accessing reliable markets by farmers despite the existence of multiple actors operating in the villages can be regarded as a sign that the actors do not operate from the value chain perspective in which issues of production, processing, packaging and linkage to markets are all addressed. It can be further argued that the situation is exacerbated by the absence of actor networks and coalitions that could have facilitated a value chain approach to enterprise promotion. They operate as disjointed elements rather than a synergistic system (Sumberg, 2005). Similar observations have been made by other researchers (Spielman, 2005; World Bank, 2007; Klerkx and Leeuwis, 2008; Spielman, Ekboir et al., 2009; Klerkx, Aarts et al., 2010) who have argued that actors in agriculture need to operate as a coherent system in order to effectively support agricultural innovation and development. The need for external actors, in the context of reforms in extension and advisory services, to operate beyond technology so that they also include areas such as organizational change, value addition and market development is emphasized by a number of scholars (Spielman, 2005; Chipeta, 2006; Spielman, Ekboir et al., 2009; Madzudzo, 2011). In this study, evidence of poor networks or coordination of the actors includes the existence of multiple operational committees in the villages which farmers complain of as duplication and time consuming. Interestingly, study participants made no mention of the institutions created under the new agricultural extension policy to articulate and respond to farmer demand (i.e. Village Agriculture Committee, Area Stakeholder Panel, District Stakeholder Panel and District Agriculture Executive Coordinating Committee). It can also be suggested that capacity strengthening for the committees may not be properly addressed by individual actors, considering the number of villages they operate in, committees established and multiple positions held by some farmers. This could be one of the contributing factors to farmers' inadequate capacity to engage actors regarding their demands, needs and desired responsiveness. Mangheni and Mubangizi (2007) 
stress the need for building capacity of local farmer organisations to enable them to effectively articulate demands to actors. The multiplicity of local committees found in this study, each identified by the names of the initiating organisations or their programmes, may undermine farmers' cohesion as they have allegiance to the actors who facilitated their committee's formation and not to work jointly to achieve their common goals as farmers.

Pluralism in agricultural extension has offered increased opportunities to farmers in the study villages to access information and knowledge from diverse sources. On the other hand the findings suggest that pluralism has also created conflicts in terms of messages and approaches. It can be argued that the situation is a manifestation of poor coordination amongst the actors. Although exploring areas of collaboration and coordination amongst the actors may not completely eliminate conflicts, it can minimise obvious overlaps and create room for understanding each other's areas of operation and focus. Although operational structures created under Malawi's extension reforms provide a potential platform for actors to interact and facilitate understanding and clarification of one another's programmes and modes of operation, their effectiveness is questionable. Policy implementation may face challenges because policy changes rarely build on strengths of previous policies, nor do they address non technical issues that may facilitate behaviour change within organisations (Leeuwis, 2004; Davidson, 2007; Azadi and Filson, 2009). The need for an operational framework for standards and quality check in service provision is urgent.

\section{Conclusion}

Pluralistic extension has come to stay, and presents a rich and complex picture that cannot be described as completely demand driven or responsive. Although there are claims of demanddriven interventions being implemented, the demand side is shown in this study to be rather weak, resulting in external actors dictating what they want and leaving farmers on the receiving end. The disadvantaged position of farmers emanates from the poor coordination of actors who operate independently without exploring how they can benefit from synergies of pluralism and address issues from value chain perspectives for the benefit of both their organisations and farmers. Weakened farmers' organisations have failed to engage actors in order to facilitate responsiveness of interventions. Continuity of interventions is affected due to inability of actors to empower farmers to take ownership from the onset of activities. Despite farmers' positive views on pluralism, partnership between farmers and external actors will facilitate improvement of their social and economic status by enabling them to produce, access both input and produce markets and make informed decisions.

The study findings suggest that extension in Malawi experiences 'system failure' (Klerkx, Hall et al., 2009). This is manifest in lack of coordination and provision of services that do not address needs of the smallholder farmers. Innovation system actors from the public, private and NGO sectors fail to facilitate effective interaction within the system, despite the establishment of formal coordination structures. The situation can be attributed to weak monitoring mechanism and lack of drivers or champions to kick start the processes of change (Poulton, Dorward et al., 2010). The system needs to reinvent in order to create new forms of 
horizontal communication between actors to complement the provision of material inputs to farmers: Klerkx, de Grip et al. (2006) and Poulton, Dorward et al. (2010), among others, argue that in decentralized extension systems horizontal coordination of actors encourages interaction and addresses conflicts that arise from differences in goals and because perceptions of actors as competitors limit the extent to which they can interact.

The study therefore suggests that interaction among actors can be improved by establishment of horizontal coordination teams at different levels. These learning teams need initial funding source for preparation and acquisition of materials to facilitate interactive learning. The fund could be used to establish platforms for public and private sector actors to identify their relevant roles in the value chains of different enterprises (Klerkx and Leeuwis, 2008; Klerkx, Hall et al., 2009). However the availability and willingness of an organisation to volunteer leading the process is crucial to set the pace of mobilising actors and establish linkage for the social learning process. These learning teams are not the same as formal coordination structures commonly established as part of extension system reform. The teams are established based on the interests of actors in various enterprises to assist not only farmers in their livelihoods but also their organisations to achieve their goals.

There is also need to strengthen the role of local government bodies as intermediaries in decentralized extension. The behaviour of actors to supply farmers with what they think they need is a manifestation of weak monitoring mechanism by local government to ensure that actors are accountable for their actions. The study suggests that service providers should facilitate articulation of demands by farmers (cf. Klerkx, de Grip et al., 2006; Rivera and Sulaiman, 2009). The justification is that provision of extension has been top down for years and it requires commitment from the actors to create an environment for change to flourish through enabling farmers to build their capacity on how and what to demand.

Horizontal coordination also addresses farmers' challenge of market access. Interventions by local government through decentralized meetings of actors enable farmers to identify and link with market players (Poulton, Dorward et al. 2010). The authors' suggestion (ibid.) on critical commodity chains where a state market agency buys strategic commodities from smallholder farmers is appropriate for the study area because majority of farmers sell what they produce in order to buy food. The assumption is that assurance of a ready market can trigger farmers' motivation and willingness to invest in farming and produce more. However the approach requires policy intervention to engage and negotiate market deals on behalf of smallholder farmers. Organisation of farmers in commodity groups by innovation system actors is crucial to mobilise produce that satisfies buyers' requirements and to provide a platform to engage with buyers and bargain on prices.

The study concludes that efficiency of decentralized extension in Malawi can be enhanced with policy intervention to respond to farmers' marketing needs and provision of funding for multi-stakeholder learning platforms that will encourage interaction and coordination of innovation system actors. 


\section{References}

Anderson, J. \& Feder, G. (2003) Rural Extension Services. Agriculture and Rural Development. World Bank Research Working Paper 2976. Washington,DC: World Bank..

Anderson, J.R. \& Feder, G. (2004) Agricultural Extension: Good Intentions and Hard Realities. World Bank Research Observer, 19(1), pp. 41-60.

Assefa, A., Waters-Bayer, A., Fincham, R. \& Mudhara, M. (2009) Comparison of frameworks for studying grassroots innovation: Agricultural Innovation Systems and Agricultural Knowledge and Information Systems. In: Sanginga, R.C., Waters-Bayer, A., Kaaria, S., Njuki, J. \& Wettasinha, C. (Eds.), Innovation Africa: enriching farmers' livelihoods.London, Earthscan, pp. 35-56.

Axinn, G.H. (1997) Challenges to agricultural extension in the twenty first century. In: Scarborough, V., Killough, S., Johnson, D. \& Farrington, J. (Eds), Farmer Led Extension: Concepts and Practices. London, Intermediate Technology Publications, pp. 13-22.

Azadi, H. \& G. Filson (2009) Comparative study of agricultural extension systems: A systemic view. Outlook on Agriculture, 38, pp. 337-347.

Bebbington, A. \& Sotomayor, O. (1998) Demand-led and poverty-oriented ... Or just subcontracted and efficient? Learning from (semi-) privatized technology transfer programmes in Chile. Journal of International Development, 10(1), pp. 17-34.

Beynon, J., Akroyd, S., Duncan, A. \& Jones, S. (1996) Financing the Future: Options for Agricultural Research and Extension in Sub-Saharan Africa. Oxford: Oxford Policy Management.

Biggs, S. (1990) A multiple source of innovation model of agricultural research and technology promotion. World Development, 18(11), pp. 1481-1499.

Brookfield, H. (2008) Family farms are still around: Time to invert the old agrarian question. Geography Compass, 2(1), pp. 108-126

Carr, E.R. (2008) Men's Crops and Women's Crops: The Importance of Gender to the Understanding of Agricultural and Development Outcomes in Ghana's Central Region. World Development, 36(5), pp. 900-915.

Chinsinga, B. (2008) Ministries of Agriculture: Structures, Capacity and Coordination at District Level in Malawi. Future Agricultures. Retrieved March 26, 2011, from www.futureagricultures.org.

Chipeta, S. (2006) Demand Driven Agricultural Advisory Services. Lindau: Swiss Center for Agricultural Extension and Rural Development, for the Neuchatel Initiative Group. 
Chipeta, S., Christoplos, I. \& Katz, E. (2008) Common Framework on Market-Oriented Agricultural Advisory Services. Neuchâtel, Switzerland: Neuchâtel Group.

Cromwell, E. \& Winpenny, J. (1993) Does Economic Reform Harm the Environment? A Review of the Structural Adjustment in Malawi. Journal of International Development, 5(6), pp. 623-649.

Davidson, A. P. (2007) Participation, education, and pluralism: towards a new extension ethic. Development in Practice, 17(1), pp. 39 - 50.

Douthwaite, B., Keatinge, J.D.H. \& Park, J.R. (2001) Why promising technologies fail: the neglected role of user innovation during adoption. Research Policy, 30(5), pp. 819-836.

Engel, P. \& Salomon, M. (1997) Rapid Appraisal of Agricultural Knowledge Systems: RAAKS resource box. Amsterdam, Royal Tropical Institute.

Farrington, J. (1995) The changing public role in agricultural extension. Food Policy, 20(6), pp. 537-544.

Garforth, C. (2005) The Challenges of Agricultural Extension. In: Levy, S. (Ed), Starter Packs: A Strategy to Fight Hunger in Developing Countries? Lessons from Malawi Experience 1998 -2003. Wallingford, CABI Publishing, pp. 175-192.

Garforth, C. (2011). Education, training and extension for food producers. Science review: SR16B. Foresight project on Global Food and Farming Futures. London: Government Office for Science. Published January 2011 online at:

http://www.bis.gov.uk/assets/bispartners/foresight/docs/food-and-farming/science/11-562sr16b-education-training-extension-for-food-producers.pdf

GoM (1998) The National Decentralisation Policy. Lilongwe: Ministry of Local Government.

GoM (2000) Agriculture Extension in the New Millennium: Towards Pluralistic and Demand driven services. Lilongwe: Ministry of Agriculture

GoM (2009) National Census for Agriculture and Livestock. Lilongwe: National Statistical Office.

GoM (2010a) The Agricultural Sectorwide Approach (ASWAp): Malawi's Prioritised Development Agenda 2010-2014.Lilongwe: Ministry of Agriculture.

GoM (2010b) Lead Farmer Concept - Implementation Guidelines. Lilongwe: Department of Agricultural Extension Service.

Government of Kenya (2007) National Agricultural Sector Extension Policy Implementation Framework. Nairobi: Agricultural Sector Coordination Unit. 
Harrigan, J. (2003) U-Turns and Full-Circles: Two Decades of Agricultural Reform in Malawi 1981-2000. World Development, 31(5), pp. 847-863.

Juma, C. (2011) The New Harvest: agricultural innovation in Africa. Oxford: Oxford University Press.

Kabuye, E.S. \& Mhango, J.A. (2005) A Brief History of Agricultural Extension in Malawi 1948 -2000. Lilongwe: Ministry of Agriculture.

Klerkx, L., Aarts, N. \& Leeuwis, C. (2010) Adaptive management in agricultural innovation systems: The interactions between innovation networks and their environment. Agricultural Systems, 103(6), pp. 390-400.

Klerkx, L. \& Leeuwis, C. (2008) Balancing multiple interests: Embedding innovation intermediation in the agricultural knowledge infrastructure. Technovation, 28(6), pp. 364378.

Klerkx, L., De Grip, K. \& Leeuwis, C. (2006) Hands off but strings attached: the contradictions of policy-induced demand-driven agricultural extension. Agriculture and Human Values, 23 (2), pp. 189-204.

Klerkx, L., Hall, A. \&Leeuwis, C. (2009) Strengthening agricultural innovation capacity: are innovation brokers the answer? International Journal of Agricultural Resources, Governance and Ecology, 8(5), pp. 409-438.

Klerkx, L. \& Leeuwis, C. (2008) Matching demand and supply in the agricultural knowledge infrastructure: Experiences with innovation intermediaries. Food Policy, 33(3), pp. 260-276.

Knorr, J. \& Gerster-Bentaya, M. (2007) The History of Agricultural Extension in Malawi. Weilkersheim: Margraf Publishers GmbH.

Leeuwis, C. (2004) Fields of conflict and castles in the air. Some thoughts and observations on the role of communication in public sphere innovation processes. The Journal of Agricultural Education and Extension, 10(2), pp. 63-76.

Madzudzo, E. (2011) Role of Brokerage in Evolving Innovation Systems: A Case of the Fodder Innovation Project in Nigeria. The Journal of Agricultural Education and Extension, 17(2), pp. $195-210$.

Mangheni, M.N. \& Mubangizi, N. (2007) Requirements for Successful Privatised Contract Farmer-lead Agricultural Extension: Lessons from Uganda's National Advisory Services. In: Mangheni, M.N. (Ed), Experiences, Innovations and Issues in Agricultural Extension in Uganda: Lessons and Prospects. Kampala, Fountain Publishers, pp. 13-32.

Masangano, C. \& Mthinda, C. (2010) Agricultural Extension in Malawi. Lilongwe: Bunda College of Agriculture. 
Masanjala, W.H. (2006) Cash Crop Liberalization and Poverty Alleviation in Africa: Evidence from Malawi. Agricultural Economics, 35, pp. 231-240.

Parkinson, S. (2009) When farmers don't want ownership: reflections on demand-driven extension in sub-Saharan Africa. The Journal of Agricultural Education and Extension, 15(4), pp. 417-429.

Poulton, C., Dorward, A. \& Kydd, J. (2010) The Future of Small Farms: New Directions for Services, Institutions, and Intermediation. World Development, 38(10), pp. 1413-1428.

Rivera, W. \& Sulaiman, R.V. 2009. Extension: object of reform, engine for innovation. Outlook on Agriculture, 38(3), pp. 267-273.

Rivera, W. \& Alex, G. (2004) Demand-driven approaches to agriculture extension. Case studies of international initiatives. Volume 3 in: Agriculture and Rural Development Discussion Paper 10 Extension Reform for Rural Development. Washington: The World Bank.

Scarborough, V. (1990) Agricultural Policy Reforms under Structural Adjustment in Malawi. London. Wye College, University of London.

Spielman, D.J. (2005) Innovation Systems Perspectives on Developing-Country Agriculture: A Critical Review. ISNAR Discussion Paper 2. Washington, D.C.: International Food Policy Research Institute.

Spielman, D., Davis, K., Negash, M. \& Ayele, G. (2011) Rural innovation systems and networks: findings from a study of Ethiopian smallholders. Agriculture and Human Values, 28 (2), pp. 195-212.

Spielman, D.J., Ekboir, J. \& Davis, K. (2009) The art and science of innovation systems inquiry: Applications to Sub-Saharan African agriculture. Technology in Society, 31(4), pp. 399-405.

Strauss, A. \& Corbin, J. (1998) Basics of Qualitative Research: Techniques and Procedures for Developing Grounded Theory (2nd edition). London: Sage Publications.

Sulaiman, V.R. \& Hall, A. (2002) Beyond technology dissemination: reinventing agricultural extension. Outlook on Agriculture, 31(4), pp. 225-233

Sumberg, J. (2005) Systems of innovation theory and the changing architecture of agricultural research in Africa. Food Policy, 30(1), pp. 21-41.

van den Ban, A. (2006) World Trend in Agricultural Extension. In: Proceedings of the 2nd International Conference on Agricultural Education and Environment, October 2004, Souwon, Korea. Bangkok: Regional Office for Asia and the Pacific, Food and Agriculture Organization 
World Bank (2007) Enhancing Agricultural Innovation: How to Go Beyond the Strengthening of Research Systems. Washington, D.C.: The World Bank.

World Bank (2008) World Development Report 2008. Washington, D.C.: The World Bank. 
Table 1: Summary of sources of information listed by men and women in the villages

\begin{tabular}{|c|c|c|c|c|c|}
\hline \multirow[t]{2}{*}{ Category } & \multirow[t]{2}{*}{ Actors } & \multicolumn{2}{|c|}{ Matimba Village } & \multicolumn{2}{|c|}{$\begin{array}{l}\text { Gomani II } \\
\text { Village }\end{array}$} \\
\hline & & Male & Female & Male & Female \\
\hline \multirow[t]{4}{*}{ Microfinancing } & FITSE & $\mathrm{x}$ & $\mathrm{x}$ & $\mathrm{x}$ & - \\
\hline & CADECOM & - & - & $\mathrm{x}$ & $\mathrm{x}$ \\
\hline & Microloan & $\mathrm{x}$ & $\mathrm{x}$ & $\mathrm{x}$ & $\mathrm{x}$ \\
\hline & MRFC & $\mathrm{x}$ & - & - & - \\
\hline \multirow[t]{13}{*}{$\begin{array}{l}\text { Extension and } \\
\text { training }\end{array}$} & $\begin{array}{l}\text { Ministry of } \\
\text { Agriculture }\end{array}$ & $\mathrm{x}$ & $\mathrm{x}$ & $\mathrm{x}$ & $\mathrm{x}$ \\
\hline & Total Land Care & $\mathrm{x}$ & - & $\mathrm{X}$ & $\mathrm{x}$ \\
\hline & NASFAM & $\mathrm{x}$ & $\mathrm{x}$ & - & - \\
\hline & Heifer International & - & - & $\mathrm{x}$ & $\mathrm{x}$ \\
\hline & ICRISAT & $\mathrm{x}$ & - & - & - \\
\hline & AGRA & - & - & $\mathrm{x}$ & - \\
\hline & ICRAF & - & - & $\mathrm{x}$ & $\mathrm{x}$ \\
\hline & RLEEP & $\mathrm{x}$ & - & $\mathrm{x}$ & - \\
\hline & Ministry of Forestry & $\mathrm{x}$ & $\mathrm{x}$ & $\mathrm{x}$ & $\mathrm{x}$ \\
\hline & Ministry of Health & $\mathrm{x}$ & $\mathrm{x}$ & $\mathrm{X}$ & $\mathrm{x}$ \\
\hline & CARD & $\mathrm{x}$ & $\mathrm{x}$ & $\mathrm{x}$ & $\mathrm{x}$ \\
\hline & $\begin{array}{l}\text { Mudzi Wathu } \\
\text { Community Radio } \\
\text { Station }\end{array}$ & $\mathrm{x}$ & - & $\mathrm{x}$ & $\mathrm{x}$ \\
\hline & $\begin{array}{l}\text { Farmers Voice } \\
\text { Radio (FVR) }\end{array}$ & - & - & $\mathrm{x}$ & $\mathrm{x}$ \\
\hline \multirow[t]{3}{*}{ Social Service } & $\begin{array}{l}\text { District Assembly - } \\
\text { Social Cash } \\
\text { Transfer }\end{array}$ & $\mathrm{x}$ & $\mathrm{x}$ & $\mathrm{x}$ & $\mathrm{x}$ \\
\hline & Home based care & $\mathrm{x}$ & $\mathrm{x}$ & $\mathrm{x}$ & $\mathrm{x}$ \\
\hline & Orphan Care & $\mathrm{x}$ & $\mathrm{x}$ & $\mathrm{x}$ & $\mathrm{x}$ \\
\hline
\end{tabular}

Source: focus group discussions and key informant interviews conducted in 2011 
Table 2: Comparison of some key innovations in maize and groundnuts before and after pluralism

\begin{tabular}{|c|c|c|c|}
\hline Enterprise & Innovations & Before pluralism & After pluralism \\
\hline \multirow[t]{8}{*}{ Maize } & Ridge spacing & Wide $90 \mathrm{~cm}$ or more & $75 \mathrm{~cm}$ \\
\hline & Plant spacing & $90 \mathrm{~cm}$ & $15 \mathrm{~cm}$ or $30 \mathrm{~cm}$ \\
\hline & $\begin{array}{l}\text { Number of seed } \\
\text { per hole }\end{array}$ & 3 & 1 or 2 \\
\hline & Varieties & Local & Various improved \\
\hline & $\begin{array}{l}\text { Method of } \\
\text { application of } \\
\text { fertilizer }\end{array}$ & $\begin{array}{l}\text { Calibrated fertilizer } \\
\text { cups }\end{array}$ & Bottle tops \\
\hline & $\begin{array}{l}\text { Time of fertilizer } \\
\text { application }\end{array}$ & $\begin{array}{l}\text { Based on plant } \\
\text { height }\end{array}$ & $\begin{array}{l}\text { Based on number } \\
\text { of days after } \\
\text { planting }\end{array}$ \\
\hline & $\begin{array}{l}\text { Input and output } \\
\text { markets }\end{array}$ & $\begin{array}{l}\text { Organised, reliable, } \\
\text { found in the village, } \\
\text { farmers felt } \\
\text { protected from } \\
\text { traders }\end{array}$ & $\begin{array}{l}\text { Liberalized } \\
\text { markets, not } \\
\text { reliable, } \\
\text { widespread, } \\
\text { farmers feel } \\
\text { insecure to buyers } \\
\text { due to price }\end{array}$ \\
\hline & $\begin{array}{l}\text { Methods of } \\
\text { making compost }\end{array}$ & $\begin{array}{l}\text { Didn't know about } \\
\text { compost }\end{array}$ & $\begin{array}{l}\text { Various methods } \\
\text { of making } \\
\text { compost }\end{array}$ \\
\hline \multirow[t]{4}{*}{ Groundnuts } & Ridge spacing & $90 \mathrm{~cm}$ or more & $75 \mathrm{~cm}$ \\
\hline & Varieties & $\begin{array}{l}\text { Non improved } \\
\text { indeterminate, late } \\
\text { maturing }\end{array}$ & $\begin{array}{l}\text { Improved } \\
\text { determinate, early } \\
\text { to medium } \\
\text { maturing }\end{array}$ \\
\hline & $\begin{array}{l}\text { Prevention of } \\
\text { aflatoxin }\end{array}$ & $\begin{array}{l}\text { No systematic } \\
\text { procedure for } \\
\text { drying }\end{array}$ & $\begin{array}{l}\text { Drying groundnut } \\
\text { upside down in a } \\
\text { cone shaped heap }\end{array}$ \\
\hline & Output market & Organised & $\begin{array}{l}\text { Liberalized } \\
\text { markets, un } \\
\text { reliable, } \\
\text { widespread }\end{array}$ \\
\hline $\begin{array}{l}\text { Farmer } \\
\text { organisation }\end{array}$ & $\begin{array}{l}\text { Extension agents } \\
\text { interaction with } \\
\text { farmers }\end{array}$ & $\begin{array}{l}\text { Farmer clubs at } \\
\text { village level }\end{array}$ & $\begin{array}{l}\text { Various } \\
\text { subcommittees at } \\
\text { village level }\end{array}$ \\
\hline
\end{tabular}

Source: focus group discussions and key informant interviews conducted in 2011 
Figure 1Schematic farmer-centric representation of actors within an innovation system

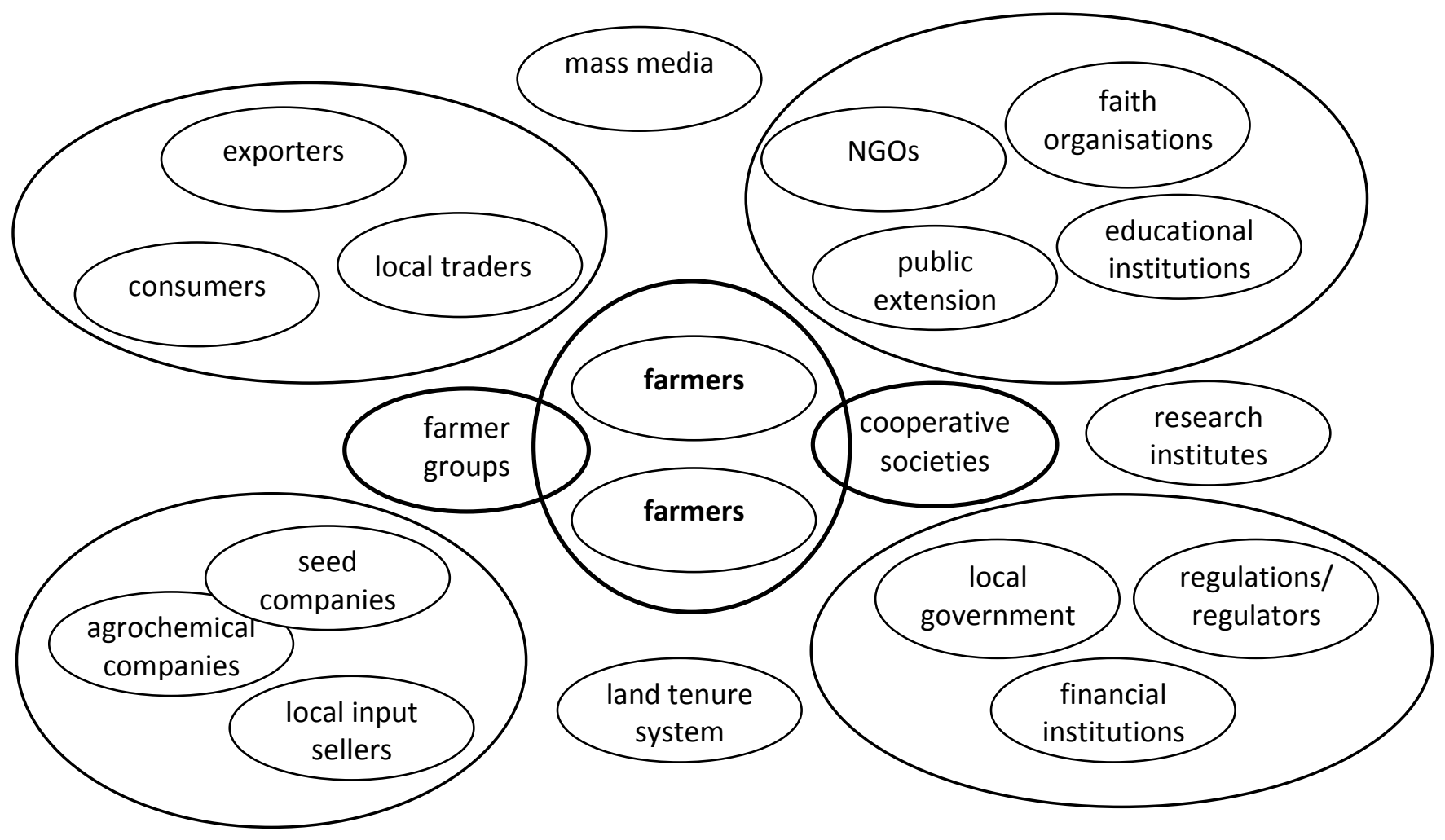

